\title{
Intervenção estatal sobre o domínio econômico: fiscalização, incentivo e planejamento
}

\author{
Althair Ferreira dos Santos Junior ${ }^{1}$
}

\begin{abstract}
Resumo
Nos diferentes momentos que a história e a filosofia política relatam e analisam, a presença do poder político teve diferentes graus de ingerências na sociedade e no plano das relações econômicas. Neste trabalho, percorrem-se os momentos em que se fizeram presentes, de modo mais expressivo, os ideários do Estado Absolutista, do Estado Liberal, do Estado Social e do Estado Neoliberal para constatar a influência de cada modelo estatal na formulação do regime jurídico-econômico do Estado brasileiro, traçado pelo Art. 170 da Constituição Federal. As hipóteses de intervenção do Estado sobre a ordem econômica estão previstas no Art. 174 do referido diploma legal (fiscalização, incentivo e planejamento) e só se justificam se visarem ao atendimento dos fins do regime jurídico inaugurado em 1988.
\end{abstract}

Palavras-Chave: Estado; Intervenção; Ordem Econômica.

\section{Introdução}

O quantum de Estado no domínio econômico é uma opção dos cidadãos nacionais que está registrada, contemporaneamente, em regra, em nível Constitucional. No caso brasileiro, os fundamentos, princípios e fins da ordem econômica estão estabelecidos no Art. 170 da Constituição Federal.

O Art. 174 do mesmo diploma legal traz as hipóteses que autorizam a intervenção do Estado sobre a ordem econômica nacional por meio da fiscalização, incentivo e planejamento. Esta intervenção só é legítima, porém, quando o Estado a realiza para dar concretude aos princípios e fins constitucionalmente estabelecidos para reger as relações sócio-econômicas.

Ao inaugurar a referida ordem econômica, o legislador constituinte lançou mão de valores que foram conquistados ao longo da história moderna. Alguns desses valores são

1 Acadêmico do 40 ano de Direto da Universidade Estadual de Londrina; Bolsista PIBIC/CNPq; membro participante do Projeto de Pesquisa "Estado e Relações Empresariais: Diálogos Filosóficos e Jurídicos diante da Regulação Estatal sobre a Ordem Econômica Nacional" do Departamento de Direito Público da Universidade Estadual de Londrina, sob coordenadoria da profạ. Drạ. Marlene Kempfer Bassoli, orientadora do presente Artigo Científico. . 
fruto de conquistas liberais, outros são provenientes de ideais de justiça social, que emergiram à cena política com o Estado Social.

Os diferentes modelos de Estado, desde os primórdios do Estado Moderno, o Estado Absolutista, passando pelos Estados Liberal e Social, até o recente Estado Neoliberal, revelam, cada um a seu tempo, fontes importantes de investigação e reflexão acerca da construção dos modelos de Estado atuais.

Nesta pesquisa destacou-se: as hipóteses em que, contemporaneamente, está o Estado autorizado a atuar no ambiente econômico; os limites para esta ingerência. São questões dessa natureza que têm se apresentado aos intérpretes do Direito, alimentando discussões importantíssimas acerca dos cenários político, jurídico e econômico.

\section{Estado Absolutista}

É importante dizer que a abordagem inicial é feita a partir do Estado Absolutista, a primeira versão do Estado Moderno, pois não se verifica, no período medieval, a presença de estruturas capazes de oferecer o substrato necessário ao conceito de Estado. Não se pode negar que existiram estruturas de poder à época, como por exemplo, a Igreja. No entanto, estas não convergiram uniformemente para a formação do Estado. Sobre isso, bem ensina Lourival Vilanova (2003, p. 342):

Eram estruturas de poder a Igreja, as cidades livres, os senhores feudais e seus vassalos, o sacro Império Romano, os grêmios e corporações e outros entes intercalares. Estrutura de poder houve, sem alcançar, todavia, a concentração e a preeminência que caracterizam a estrutura de poder estatal. Estruturas de poder político eram, sem que o político confluísse, potenciando-se, em Estados.

É somente com o Estado Moderno que aparece o conceito de Estado como instituição detentora de um poder exclusivo, dotada de autonomia nas tomadas de decisão e formulação de normas sem subordinação aos valores religiosos que imperaram durante a Idade Média. Esta nova configuração fundamenta o Estado no princípio da soberania plena no tocante ao exercício do poder em um território e diante de um povo. Têm-se, com isso, os elementos basilares do Estado Moderno: Poder soberano, governo (que exercita o poder), território e povo (STRECK; M ORAIS, 2003, p. 24). 
Feita essa observação, passa-se à análise do Estado Absolutista. Como este modelo estatal surgiu baseado na idéia de soberania, é interessante notar a distinção de duas fases pelas quais passou, a partir da teorização da soberania como critério diferenciador, conforme apresenta Paulo Bonavides (2007, p. 35-36). Na primeira fase, segundo o autor, surge o regime da Monarquia absoluta de direito divino, legitimada pela concepção de que 0 poder monárquico seria fruto da outorga de Deus e tem como teóricos Maquiavel e Bodin. Na segunda fase, o poder soberano adviria não mais de uma divindade, mas sim do próprio homem por meio de sua razão com a elaboração de um Contrato Social, distanciando-se dos padrões teológicos e metafísicos do clero, que limitavam o poder do monarca. É a expressão do pensamento de Hobbes (apud BONAVIDES, 2007, p. 36).

Aliás, a segunda fase testemunha, com toda evidência, a secularização do Absolutismo em bases filosóficas e consensuais. Haja vista a esse respeito 0 Contratualismo social que introduz com Hobbes uma nova fundamentação do poder, que já não promana da divindade, mas do Homem e de sua razão prática, dos imperativos racionais que afiançam a sobrevivência ameaçada da espécie humana, segundo aquele grande pensador.

Em Hobbes, a existência do governo civil contrapõe-se a do Estado de Natureza. Neste, cada indivíduo igualmente se auto governa livre de qualquer interferência externa à sua própria razão. A igualdade e a liberdade de que dispõe o homem, em sua condição natural, promovem um permanente estado de guerra (HOBBES, cap. XIV), no qual imperam a discórdia, a violência e o terror, o que levaria ao extermínio inevitável do gênero humano; é a teoria do medo. Por isso, seria necessário avançar em direção à criação de um Estado Civil.

Para tanto, cada homem renunciaria a uma porção de sua liberdade, por meio de um Contrato Social, entregando a um soberano a tarefa de prezar pela ordem e segurança de seus súditos, reduzindo nele, soberano, a vontade geral. "O homem perdia a liberdade, mas ganhava, em troca, a certeza da conservação", como sumariza Bonavides (2007, p. 37). Estavam lançadas as bases do Estado Absolutista, verificado nas monarquias européias dos séculos XVII e XVIII.

No Estado Absolutista, o soberano detém autoridade ilimitada ao governar, pois na medida em que os homens tentam escapar do estado de guerra por meio do consenso (Contrato Social), investem o Estado de poder para manter a sociedade em paz, restando ao 
soberano a titularidade deste poder. 0 contrato social é estabelecido entre os homens e não entre estes e o Estado. "Na monarquia absoluta, o governo (=monopólios da violência e da tributação) consistia em um monopólio pessoal de um único indivíduo" (GRAU, 2006, p. 16). A vontade geral estava contida na vontade do soberano.

Luís XIV, que governou a França no século XVII, é o maior exemplo de monarca absolutista. A ele é atribuída a célebre frase "O Estado sou Eu", em que se nota a típica característica do Estado Absoluto: Estado e governo se confundem na pessoa do monarca.

\section{Estado Liberal}

A institucionalização do poder - Estado Absolutista - trouxe a estabilidade necessária para o desenvolvimento dos comércios, dos mercados, enfim, do capitalismo e, por conseguinte, a emersão de uma nova classe, a burguesia, que não tinha acesso ao poder político, pois, como já dito, todo poder concentrava-se nas mãos do soberano. No final do século XVIII, uma nova fase do Estado Moderno é inaugurada tendo como marco inicial as revoluções burguesas, sobretudo a que se deflagrou na França.

A estabilidade institucional desmoronou quando a participação da classe burguesa nas tomadas de decisões políticas passou a ser um contingente social da época. A burguesia, dotada de poder econômico, não se contentava mais em deixar o poder político adstrito à nobreza aristocrática. Inicia-se a fase da limitação da soberania interna, da negação da ingerência absoluta do Estado na vida da sociedade e, de maneira especial, da afirmação de direitos intocáveis, inerentes a todos os homens. São os direitos fundamentais de primeira geração formados pelo compromisso inarredável do Estado "com a liberdade e, por via de conseqüência, com os direitos políticos e civis" (BONAVIDES, p. 43). Firmam-se, assim, as bases do Estado Liberal.

No plano teórico, a referência primordial quanto aos fundamentos do liberalismo político é John Locke. 0 filósofo inglês é considerado o "ponto de partida" deste movimento e sua obra, produzida no final do século XVII, embasaria "ulterior desenvolvimento nos séculos XVIII e XIX" da doutrina liberal (GRONDONA apud BITTAR, 2007, p. 178). Por isso, é imprescindível inclinar os estudos ao pensamento político-filosófico de Locke para se compreender o nascimento deste modelo estatal. 
Locke também vislumbra a existência de um Estado de Natureza, do qual emanam direitos inalienáveis, como a vida, a liberdade e a propriedade. Porém, diferentemente de Hobbes, ele não considera o Estado de Natureza um constante estado de guerra em que 0 conflito entre os homens é sempre iminente, mas sim que os homens exercem sua liberdade segundo as leis naturais, as quais devem ser usadas racionalmente, respeitando-se, sempre, as liberdades dos demais. Ou seja, há um núcleo de direitos que provêm das leis naturais e que devem ser exercidos pela razão. Leia-se:

O’Estado de Natureza' é regido por um direito natural que se impõe a todos, e com respeito à razão, que é este direito, toda a humanidade aprende que, sendo todos iguais e independentes, ninguém deve lesar o outro em sua vida, sua saúde, sua liberdade ou seus bens;... Dotados de faculdades similares, dividindo tudo em uma única comunidade da natureza, não se pode conceber que exista entre nós uma 'hierarquia' que nos autorizaria a nos destruir uns aos outros (LOCKE, 2001, p. 84).

Por conseqüência, o Estado Civil de Locke surge não para limitar totalmente as liberdades do homem a fim de se garantir a conservação da humanidade, como quis Hobbes, mas sim para aperfeiçoar o Estado de Natureza que, por conferir igualdade aos homens, necessita de uma fonte superior a eles para dirimir e julgar os conflitos evitando o estado de guerra. Conclui-se que, para Locke, o estado de guerra é circunstancial e ocorre quando há apelo à violência, quando o homem executa as leis da natureza segundo suas paixões e não por meio da razão. Enquanto para Hobbes, a hostilidade é um elemento próprio da natureza humana.

É importante destacar que a propriedade, para o referido autor, é um direito natural e, portanto, tem sua origem antes do Estado Civil. É que os homens se apropriam dos bens disponíveis na natureza para a sua sobrevivência. Ao fazê-lo, cada homem emprega o "trabalho de seu corpo", que é propriedade individual, de modo a converter o bem natural coletivo em sua propriedade particular (LOCKE, 2001, p. 98). Logo, o Estado Civil de Locke também visa à proteção da propriedade, além da função de julgar os conflitos, já abordada anteriormente.

Não se pode deixar de mencionar que, para Locke, assim como para Hobbes, a formação do Estado civil se dá por meio do Contrato Social. No entanto, aquele inova ao considerar que os direitos naturais não podem ser dissolvidos pelo pacto firmado entre os indivíduos. Vale dizer que o consentimento dos homens condiciona-se à obediência aos 
direitos naturais, que são intocáveis, inerentes aos homens. 0 Estado que viola tais direitos, carece de legitimidade. 0 poder instituído sofre limitações a fim de prevalecerem os direitos naturais.

Para a garantia desses direitos fundamentais, é preciso estabelecer os limites da atividade política estatal. A separação e a delimitação das funções dos poderes é um dos meios para isso e aparece já na obra de Locke - para ele, há um poder executivo e um legislativo; a função jurisdicional está contida no primeiro. Posteriormente, Montesquieu fórmula, no "Espírito das Leis", a clássica tripartição dos poderes e consagra este princípio que viria a consubstanciar-se nas constituições liberais do século XIX.

0 estabelecimento de uma carta legal escrita delineando os limites e funções do Estado e protegendo os direitos fundamentais é outra nota característica dos Estados Liberais. 0 exercício do poder passa a ser balizado por leis, a partir do Contrato Social entre os indivíduos, o que implica dizer que o Estado Liberal é um Estado de Direito, posto que a "vontade geral máxima", como observa Lourival Vilanova (2003, p. 350), "é vontade constituinte, cujo produto é a Constituição, que faz do Estado um Estado-de-direiro, em sentido material".

Vê-se que as funções precípuas reputadas ao Estado em seu formato liberal estão relacionadas, nomeadamente, às seguranças interna e externa e a proteção da ordem legal, haja vista ter sido o pensamento liberal uma contrapartida aos poderes sem fim dos monarcas absolutistas. 0 Estado é limitado pela liberdade dos indivíduos de agir segundo suas vontades privadas, diga-se, a liberdade contratual, que é um direito natural.

Impede-se a interferência do Estado, sobretudo no campo econômico, como aduz Dallari (2003, p. 275), "no sentido de criar algum condicionamento à manutenção e ao uso dos bens, ou alguma restrição aos termos de qualquer contrato". Desta forma, em sua versão liberal, o Estado caracteriza-se como mínimo ou o Estado-polícia. Essas constatações são relevantes para o presente estudo como se perceberá adiante.

\section{Estado Social}

É inegável que o Estado Liberal, interferindo minimamente na vida social, trouxe benefícios, principalmente no campo econômico, onde se verificou expressivo desenvolvimento que desaguou, posteriormente, na revolução industrial e incremento do 
conhecimento técnico-científico. Outro ganho foi quanto aos direitos adquiridos pelo homem. Houve uma valorização do ser humano a partir da garantia de suas liberdades. 0 homem passou a ser o personagem principal dentro do contexto social. Por conseguinte, 0 monopólio do poder deixou de ser pessoal e tornou-se público.

Contudo, conseqüências negativas do Estado Liberal também se tornaram evidentes. Vários desses efeitos colaterais podem ser elencados, a começar pelo surgimento de um Estado de classes "arrebatado pela burguesia e, assim, posto ao serviço do sistema capitalista de produção", na dicção de Eros Grau (2006, p. 17). É que a transferência do monopólio do poder, do pessoal para o público, ocorreu apenas formalmente, uma vez que quem avoca o domínio do poder estatal é a burguesia. É ela quem assume o controle do Estado.

Conforme o referido jurista, os ideais liberais revolucionários da liberdade, igualdade e fraternidade chocaram-se com a realidade do poder econômico. Explique-se: a liberdade abafou a concorrência com o acúmulo de poder econômico, por exemplo, 0 surgimento dos trustes; a igualdade, como já dito, operou-se no terreno abstrato das leis, apenas no nível formal; e a fraternidade ganhou pouco espaço na sociedade individualista que veio a nascer, pautada na competição (GRAU, 2003, p. 22-25).

Na mesma linha crítica, e ainda sobre a questão do surgimento de classes sociais, Dalmo Dallari (2003, p. 278) reconhece a formação do proletariado, dos grandes aglomerados urbanos, dos ambientes de trabalho precários, ambos como frutos da revolução industrial. Ao mesmo passo, o Estado, posto que imbuído do princípio da não intervenção na vida sócio-econômica, não poderia agir com o objetivo de atenuar as injustiças sociais que advieram desses fenômenos. Foi assim, em resumo, que "o Estado Liberal criou as condições para sua própria superação" (DALLARI, 2003, p. 277).

A demanda por uma participação maior do Estado na vida social tornou-se enorme. A estrutura sobre a qual se construiu o Estado Liberal começou a ser desmontada, sobretudo com as reivindicações por justiça social e diminuição das desigualdades. O poder público viuse diante de uma revisão de seus papéis. A intervenção do Estado no domínio econômico figurou como necessária para corrigir as disfunções e problemas gerados pelo liberalismo, nos dizeres de Dallari (2003, p. 279), "para suavizar algumas das conseqüências mais penosas da desigualdade econômica". 
Além do papel de atuar visando à melhoria das condições sociais, frisado no parágrafo anterior, o Estado assume também a função de agente regulador da economia. 0 poder público encarrega-se de criar garantias para o próprio mercado, seja financiando, consumindo, tornando-se sócio, produtor, etc., dentro do processo econômico. Isto porque, como esclarece Grau (2006, p. 26), "não existiria o capitalismo sem que o Estado cumprisse a sua parte, desenvolvendo vigorosa atividade econômica, no campo dos serviços públicos"2.

Um exemplo desta etapa inicial da intervenção estatal é o New Deal de Roosevelt, nos Estados Unidos, como lembra Streck e Morais ${ }^{3}$ (2003, p. 62). Diante da forte crise econômica que aquele país enfrentava, impôs-se ao Estado tomar atitudes de modo a frear a devastação do mercado americano.

O surgimento dos movimentos sociais, reflexo dos problemas advindos do período de total liberdade do mercado, também fortaleceu o ideário que propugnava a maior intervenção estatal para melhor distribuir as riquezas e rearranjar a sociedade desigual que florescera junto com o Estado burguês e, desta forma, diminuir tais desigualdades.

Outro fator que contribuiu para a aceleração desse processo de aumento da ingerência estatal sobre a ordem econômica foi a deflagração das duas grandes guerras mundiais, visto que o período de guerra impôs ao Estado uma atuação positiva no sentido de controlar o consumo, organizar a produção, enfim, direcionar as necessidades em prol do esforço de guerra.

Assim, um novo modelo de Estado despontou em substituição ao modelo liberal. Era o nascer do Estado Social, o Estado Providência, cujas atenções voltaram-se não mais às liberdades, pois estas já foram conseguidas anteriormente. As conquistas a serem perseguidas estavam ligadas à justiça social, à idéia de um "valor social superior" como diz Bonavides (2007, p. 46-47). Um Estado que tinha como característica primeira a atribuição de teor social às suas instituições. A partir de então o Estado passou a ser o garantidor de benefícios sociais através de proteções jurídicas de cunho social.

2 Como exemplo destes serviços públicos prestados pelo Estado, o autor destaca o papel de integrar o capitalismo por meio do fornecimento de sistemas de transporte público de cargas e mercadorias ferroviário e marítimo - e na área da saúde através de "controle de qualidade da mercadoria trabalho" (GRAU, p. 26).

3 Nos Estados Unidos da América, com o New Deal de Roosevelt, ocorre um apoio maciço a programas de obras públicas, regulamentação de crédito, controle sobre a produção agrícola; regulação das horas de trabalho, salários mínimos; negociação coletiva; sistema abrangente de seguros sociais 


\section{Estado Neoliberal}

Logo que o modelo de Estado Social se estabeleceu definitivamente no período pós II Guerra, o movimento neoliberal nasce no plano teórico com Friedrich Hayek, ainda na década de quarenta. Era uma reação contra o Estado intervencionista e de bem-estar que surgira, de modo a reerguer a bandeira da liberdade não só política, mas também econômica que a intervenção estatal estava a derrubar (ANDERSON, 1995, p. 9).

No entanto, foi somente com as seguidas crises econômicas que ocorreram nas décadas de setenta e oitenta que os ideais do neoliberalismo ganharam forte espaço nas discussões sobre os papéis do Estado. As justificativas principais giravam em torno do déficit fiscal causado pelas concessões sociais que ocorreram no Estado Social. Por isso era necessário reduzir as tarefas delegadas ao Estado.

\footnotetext{
0 remédio, então, era claro: manter um Estado forte, sim, em sua capacidade de romper o poder dos sindicatos e no controle do dinheiro, mas parco em todos os gastos sociais e nas intervenções econômicas. A estabilidade monetária deveria ser a meta suprema de qualquer governo. Para isso seria necessária uma disciplina orçamentária, com a contenção dos gastos com bem-estar, e a restauração da taxa "natural" de desemprego, ou seja, a criação de um exército de reserva de trabalho para quebrar os sindicatos (ANDERSON, 2007, p. 11).
}

Não demorou muito para que as mudanças neoliberais, que seriam capazes de remediar a crise pela qual passavam os capitalismos ocidentais, consubstanciassem-se na prática dos Estados capitalistas. 0 formato neoliberal começou a ser usado no final da década de setenta, na Inglaterra, com Tatcher e, nos Estados Unidos, com Reagan. Após os referidos dirigentes, a agenda neoliberal é seguida em vários países europeus e também ao redor de todo o mundo.

O Estado mínimo é novamente pregado e, como destaca Anderson (2007, p. 22), este movimento é um fenômeno que ainda vige, e com força, na sociedade atual, recebendo, inclusive, a acusação de muitos por ter recrudescido as desigualdades sociais que já se faziam presentes (GRAU, 2006, p. 52). 


\section{Ordem econômica e intervenção estatal: o modelo constitucional brasileiro}

A Constituição Federal de 1988 estabeleceu em seu Art. 170 as linhas da Ordem Econômica presente no Estado brasileiro. Nos termos do referido dispositivo, a ordem econômica está "fundada na valorização do trabalho humano e na livre iniciativa, tem por fim assegurar a todos existência digna, conforme os ditames da justiça social". Em seguida, nos seus incisos, dita os princípios que a norteiam.

0 referido dispositivo constitucional liga-se, essencialmente, ao Art. 219 da Lei Maior, que aloca o mercado interno como parte integrante do patrimônio nacional, merecendo a atuação do Estado para que se viabilizem "o desenvolvimento cultural e sócioeconômico, o bem-estar da população e a autonomia tecnológica do País". Se o mercado é um patrimônio nacional, nos termos do Art. 219, justifica-se alicerçar a ordem econômica nos princípios elencados pelo Art. 170, buscando, por meio da intervenção Estatal, "assegurar a todos existência digna, conforme os ditames da justiça social".

Pela valorização do trabalho, fundamento da ordem econômica nacional, entendese que os indivíduos têm não só o direito ao trabalho, mas também que este trabalho seja digno e apropriado, "segundo uma perspectiva que atenda à concepção pessoal de adequação física, psicológica e moral" (M OREIRA, 2004 p. 107). Decorre disso a proibição a trabalhos que agridam a dignidade humana, bem como a existência de trabalho escravo no país.

Outro fundamento da ordem econômica trazido pela Lei Maior no caput do Art. 170 é a livre iniciativa. Este fundamento também encontra previsão constitucional no Art. 1으, IV. É a aplicação do princípio da liberdade no campo econômico, possuindo como desdobramentos, segundo Egon Bockmann Moreira (2004, p. 108), liberdade de instalação e alocação de investimentos, liberdade de competição e liberdade de gestão. Logo, os agentes privados que atuam no domínio econômico são livres para a tomada de decisões e aferição de seus lucros.

Todavia, a livre iniciativa não é um valor absoluto, possuindo, nas lições de Moreira (2004, p. 108), limitações no campo jurídico, por exemplo, os monopólios estatais em determinados setores.

Sobre o tema e a partir das considerações feitas, pode-se emprestar a conclusão de Luís Roberto Barroso (BARROSO, 2003, p. 53): 
0 princípio da livre iniciativa, portanto, assim como os demais, deve ser ponderado com outros valores e fins públicos previstos no próprio texto da Constituição. Sujeita-se, assim, à atividade reguladora e fiscalizadora do Estado, cujo fundamento é a efetivação das normas constitucionais destinadas a neutralizar ou reduzir as distorções que possam advir do abuso da liberdade de iniciativa e aprimorar-Ihe as condições de funcionamento.

Além dos fundamentos estabelecidos no caput do Art. 170, a Constituição relaciona os princípios que orientam a ordem econômica brasileira. São eles: soberania nacional, propriedade privada, função social da propriedade, livre concorrência, defesa do consumidor, defesa do meio ambiente, redução das desigualdades regionais e sociais, busca do pleno emprego e tratamento favorecido para as empresas de pequeno porte. Neste ponto, surge a necessidade de tecer breves considerações acerca de cada princípio.

Soberania Nacional. Com referência ao Art. 170 da Constituição, que trata da ordem econômica, o princípio da soberania dá independência ao Estado para fazer suas escolhas no campo econômico, sem subordinação a interesses externos. Os exemplos de Luís Roberto Barroso (2003, p. 56) ajudam a entender este princípio: A decretação de embargo comercial feita pelo Brasil a um outro país, de modo a proibir as exportações, obriga a sujeição de todas as empresas brasileiras; aplica-se a legislação brasileira no tocante à matéria cogente, ainda que os entes privados tenham escolhido a aplicação de norma estrangeira; a reserva de mercado em setor estratégico, etc.

Propriedade privada e função social da propriedade. A propriedade privada é direito fundamental garantido e é também inerente à livre iniciativa, enquanto propriedade de produção de bens. "Sua função [...] é, em primeiro lugar, assegurar a todos os agentes que nela atuam ou pretendem atuar a possibilidade de apropriação privada dos bens e meios de produção" (BARROSO, 2003, p. 57). A este princípio credita-se, ainda, o papel de assegurar aos agentes econômicos a proteção dos referidos bens diante dos demais entes privados e do Estado. No entanto, a propriedade deve atender também a sua função social - correta utilização dos recursos naturais, aproveitamento racional da propriedade, conservação do meio ambiente, bem-estar da vizinhança, etc. - e não apenas os interesses individuais de seu proprietário.

Livre concorrência. A instituição deste princípio na ordem econômica revela a opção da carta constitucional pelo modelo de economia de mercado, como lembra Barroso (2003, p. 58). Segundo as lições do referido jurista, o princípio da liberdade de concorrência, 
decorrente da livre iniciativa, abarca a noção de que o alcance de uma maior qualidade nos bens e serviços, bem como dos preços mais justos a eles reputados dependem da livre "competição entre os agentes econômicos, de um lado, e a liberdade de escolha dos consumidores, de outro" (BARROSO, 2003, p. 58).

Defesa do consumidor. O consumidor mereceu tratamento protetivo a nível constitucional porque, sendo a parte mais frágil da relação de consumo, fica vulnerável diante dos desvios de conduta dos que oferecem bens ou serviços. A auto-regulação do mercado, na prática, como aduz Barroso (2003, p. 58), nem sempre consegue coibir práticas abusivas, cabendo ao Estado "não apenas assegurar um mercado efetivamente concorrencial, como também criar condições eqüitativas entre partes naturalmente desiguais, ainda que de forma induzida, e assegura condições objetivas de boa-fé negocial". Como exemplo desses deveres do Estado, pode-se citar o Código de Defesa do Consumidor e OS PROCON's (M OREIRA, 2004, p. 110).

Defesa do meio ambiente. A referência ao meio ambiente no capítulo da ordem econômica feita pela Constituição, além do título próprio que possui a questão ambiental (Art. $225 \mathrm{CF}$ ), está relacionada ao princípio do desenvolvimento econômico sustentável, como aduz Moreira (2004, p. 110). Desta forma, as atividades econômicas no Brasil desenvolvidas devem estar conciliadas com a proteção do meio ambiente. Em outros termos, "o agente econômico, público ou privado, não pode destruir o meio ambiente a pretexto de exercer seu direito constitucionalmente tutelado da livre iniciativa" (BARROSO, 2003, p. 59).

Busca do pleno emprego redução das desigualdades regionais e sociais. Segundo Eros Grau, tais princípios são normas-objetivo, diretrizes dotadas "de caráter constitucional conformador, a justificar a reivindicação pela realização de políticas públicas" (2006, p. 252), ou seja, são princípios-fins que vinculam toda ação do poder público ao seu atendimento. Estão relacionados ao bem-estar coletivo, inclusive diminuindo as desigualdades regionais.

Tratamento favorecido para as empresas de pequeno porte. Segundo este princípio, o Estado tem dever normativo de "promover o fomento e 0 incentivo de pequenas empresas nacionais" (M OREIRA, 2004, p. 111). Está aplicado já em sede constitucional no Art. 179. Em sede infra-constitucional, o Estatuto da Micro-Empresa (Lei 9.841/1999) é um exemplo de aplicação deste princípio. 
Pode-se concluir que, para chegar a esta formulação, o legislador constitucional lançou mão tanto de valores que promanam do ideário liberal (livre iniciativa, propriedade privada, livre concorrência) quanto daqueles que derivam das aspirações por justiça social (valorização do trabalho, função social da propriedade, redução das desigualdades, etc.). Vêse, no mesmo sistema, a coexistência de princípios que autorizam concluir a adoção pela Constituição do modelo capitalista de produção e princípios que visam a atenuar desigualdades sociais. Conciliaram-se, em 1988, as conquistas do Estado Liberal e as do Estado Social, fundando o Estado Democrático de Direito, assim denominado pela Lei Maior em seu art. 1으 (PIM ENTA, 2002, p. 35-36).

Tais constatações são essenciais para o exame da intervenção do Estado no domínio econômico, pois toda ação interventora deve perseguir os fins instituídos pela Constituição, pautando-se, inexoravelmente, nos princípios próprios que se outorgou à ordem econômica nacional. Implica dizer que o Estado não pode, a pretexto de realizar suas funções sociais, sufocar ou eliminar a livre iniciativa, a propriedade privada. Do mesmo modo, não pode permitir que direitos sociais garantidos pelo texto constitucional sejam sufragados pela ânsia dos mercados na persecução de seus objetivos.

M odalidades de intervenção: direta e indireta

Como assinala Lyrio Pimenta (2002, p. 39), a intervenção do Estado sobre o domínio econômico pode ser divida em duas modalidades: uma direta e outra indireta. A primeira delas, a intervenção estatal direta, está prevista no Art. 173 da Constituição Federal, que em sua própria diç̧ão classifica tais hipóteses de atuação como de exploração direta de atividade econômica pelo Estado, passando ele a produzir bens ou prestar serviços por meio de sociedade de economia mista ou empresa pública. "O ente público pratica operações mercantis, atos de interposição na efetivação de trocas, agindo como os demais sujeitos que atuam nos fenômenos econômicos" (PIM ENTA, 2002, p. 39).

Aqui, o Estado rege-se pelo regime de direito privado, em consonância com o Art. 173, parágrafo $1^{0}$, de modo a afastar a concorrência desleal que surgiria com a presença de um Estado-empresário. Calha dizer que, segundo o caput do referido artigo, a intervenção direta é exceção, devendo restar demonstrados os imperativos da segurança nacional ou relevante interesse coletivo para que seja autorizada tal atividade econômica estatal. 
Já o segundo tipo de intervenção, o indireto, tem sua previsão no artigo 174, objeto de estudo mais apurado no prosseguimento deste trabalho. Na modalidade de intervenção indireta, o Estado atua como agente normativo e regulador da atividade econômica, por meio do exercício da fiscalização, incentivo e planejamento. Nesta hipótese, ao Estado é "assegurado o manejo de amplo plexo de poderes para atingir os fins constitucionalmente qualificados" (PIMENTA, 2003, p. 40). 0 ente público recebe a tarefa de proporcionar a realização da política econômica como agente externo às relações econômicas verificadas na sociedade (SCOTT, 2000, p. 96).

\section{As funções estatais de intervenção}

O caput do Art. 174 da Constituição atribuiu ao Estado brasileiro as funções de normatizar e regular a atividade econômica desenvolvida em seu território. Para a efetivação dessas funções, o referido dispositivo traz ainda três hipóteses de atuação: fiscalização, incentivo e planejamento. Ou seja, os papéis de agente normativo e regulador se expressam a partir do exercício da fiscalização, incentivo e planejamento.

Surge, então, a necessidade de delimitar as diferenças da intervenção do Estado como agente normativo e agente regulador para depois dedicar os estudos às funções de fiscalização, incentivo e planejamento - que efetivam o papel de agente normativo e regulador.

Como agente normativo, ao Estado é incumbida a tarefa de concretizar valores inerentes à ordem econômica nacional, a partir de escolhas políticas feitas pelo legislador constituinte, dando-Ihes a qualificação de normas, para orientar, organizar e harmonizar as relações sócio-econômicas dentro do contexto brasileiro. É pela função de normatização que - Estado preencherá o espaço infraconstitucional, fundamentado sempre nos princípios instituídos na Lei M aior quanto à atividade econômica (SCOTT, 2000, p. 110).

Por agente regulador da atividade econômica, entende-se que o Estado deve buscar a realização das normas já positivadas anteriormente, quando fez valer seu papel de agente normativo. Nesse sentido, submete-se uma determinada situação fática ao que foi prescrito em lei. Vê-se, portanto, que os dois papéis não se confundem, mas são dependentes entre si. Para que se possa exercer o dever de regulação, presume-se a existência de um dispositivo jurídico que o oriente. Como exemplo de órgãos que cumprem este papel, tem- 
se o CADE - Conselho Administrativo de Defesa Econômica, o Ministério da Fazenda e as Agências Reguladoras (SCOTT, 2000, p. 114-118).

Fiscalização

Esta função de intervenção indireta do Estado sobre a ordem econômica remete à idéia de poder de polícia. 0 poder público deve verificar se os agentes econômicos estão obedecendo aos ditames normativos que recaem sobre o exercício das suas respectivas atividades (BASTOS, MARTINS, 1990, p. 108). Em outros termos, explica Eros Grau (2006, p. 308):

[...] fiscalizar, no contexto deste art. 174, significa prover a eficácia das normas produzidas e medidas encetadas, pelo Estado, no sentido de regular a atividade econômica. Essas normas e medidas [...] hão de necessariamente estar a dar concreção aos princípios que conformam a ordem econômica. Por isso hão de, quando atinjam a atividade econômica em sentido estrito, necessariamente configurar intervenção sobre o domínio econômico.

Diante de eventuais distorções, desvios ou descumprimentos dos preceitos legais estipulados para reger as relações econômicas, o Estado deve dispor de meios para desvendá-los e revelá-los à sociedade para que sejam corrigidos. Por isso, é necessária a presença de instituições estatais que tenham poderes para exercer esta verificação, constatando as incompatibilidades entre certas atividades e normas jurídicas atinentes à ordem econômica. Esta função do Estado, conclui-se, visa à efetivação do que foi legalmente estabelecido.

A toda evidencia, o exercício da função fiscalizadora pressupõe que o Estado tenha exercido anteriormente seu papel de agente normativo. A ausência de uma prévia normatização delimitando a atuação do ente público impossibilita o desempenho da fiscalização. Até porque, 0 artigo em estudo determina que, para que se realize, assim como as demais previstas no mesmo texto legal, esta importante atuação deve se dar na forma da lei, ou seja, "é necessário uma norma autorizando sua realização e fixando os seus limites" (SCOTT, 2000, p. 125). Fica clara a contemplação do princípio da legalidade (GRAU, 2006, p. 308). 
Quanto à fiscalização do cumprimento das normas que compõem o ordenamento jurídico constitucional e infraconstitucional, é dever tanto da União, dos Estados, do Distrito Federal e dos Municípios, em suas respectivas competências, construir um sistema fiscalizatório formado por um conjunto de órgãos voltados a esta finalidade.

Há setores do domínio econômico que, pela relevância que possuem, exigem a confluência das atuações de todas as esferas políticas. Cite-se, por exemplo, a questão ambiental em que se estabelece a competência comum (Art. 23, VI, CF) e concorrente (24, $\mathrm{VI}, \mathrm{CF}$ ) entre todos os entes federativos, exigindo um sistema fiscalizatório integrado.

Atualmente, tem-se o SISNAM A - Sistema Nacional do M eio Ambiente - instituído pela Lei 6.938/1981, sendo constituído pelos órgãos e entidades da União, dos Estados, do Distrito Federal, dos Municípios e pelas Fundações instituídas pelo Poder Público, estruturada da seguinte forma, segundo o Art. 6ㅇ, I ao VI da Lei 6.938/1981:

- Órgão Superior: 0 Conselho de Governo;

- Órgão Consultivo e Deliberativo: 0 Conselho Nacional do Meio Ambiente - CONAM A;

- Órgão Central: 0 M inistério do M eio Ambiente - M M A;

- Órgão Executor: 0 Instituto Brasileiro do Meio Ambiente e dos Recursos Naturais Renováveis - IBAM A;

- Órgãos Seccionais: os órgãos ou entidades estaduais responsáveis pela execução de programas, projetos e pelo controle e fiscalização de atividades capazes de provocar a degradação ambiental;

- Órgãos Locais: os órgãos ou entidades municipais, responsáveis pelo controle e fiscalização dessas atividades, nas suas respectivas jurisdições.

Incentivo

O Estado se põe a incentivar a atividade econômica quando pretende estimular dado setor da economia. Neste sentido, a idéia de incentivo liga-se ao planejamento, tema do próximo ponto, pois o incentivo proposto pelo Estado requer programação e organização criteriosa acerca da área econômica que se quer aquecer, por exemplo.

Este incentivo proveniente do Estado pode se dar no sentido de desestimular o agente econômico, conduzindo-o a uma imobilização ou ainda uma retração, como aduz Paulo Scott (2000, p. 127), "desde que tal comportamento vá ao encontro do interesse 
público". Ou seja, os incentivos não produzem apenas efeitos positivos ao estimular uma determinada atividade econômica, mas também geram efeitos negativos que ocorrem quando sua concessão em certas áreas ou atividades provoca o retrocesso em outras áreas que não receberam tal incentivo.

A própria Constituição, além desta previsão genérica de incentivo constante no Art. 174, traz uma previsão específica quanto ao estímulo de empresas de pequeno porte e microempresas, presente no Art. 179 da Carta Magna.

As considerações feitas no ponto anterior quanto à questão da previsão legal, estendem-se também ao incentivo. 0 que quer dizer que o incentivo só se opera mediante cominação legal que o defina especificamente, porque, como já dito, esta é a interpretação que decorre do próprio Art. 174 da CF.

Cabe notar que o incentivo não é cogente para a iniciativa privada, da mesma forma que o planejamento não o é. Em linhas gerais, posto que no seguinte tópico o tema será explicado, o incentivo não obriga o agente (privado) destinatário, deixando-o atrelado à

política estimuladora. Do contrário, as ações de incentivo devem ser persuasivas, demonstrando ao agente econômico que é proveitoso aderir àquela indicação.

\section{Planejamento}

Inicia-se a explanação acerca do planejamento pela noção de intervenção por indução, ensinada por Eros Grau (2006, p. 148-149). As normas de intervenção por indução, ao contrário das que acontecem por direção, não são dotadas de cogência, de obrigatoriedade. São normas dispositivas. Àquele a quem se destina este tipo de norma "resta aberta a alternativa de não se deixar por ela seduzir, deixando de aderir à prestação por ela veiculada".

Tal consideração preliminar é importante para a compreensão da noção constitucional de planejamento, haja vista que o Artigo 174 da Carta Magna desenha-o como determinante para o setor público e indicativo para o setor privado. O Planejamento Estatal, destaque-se, não vincula os agentes econômicos privados, que vão aderir ou não ao plano traçado pelo poder público, segundo suas próprias conveniências. Com o intuito de alcançar certos objetivos, o Estado convida os agentes privados a aderirem às estratégias estipuladas por ele. Finaliza Grau (2006, p. 311): 
Os planos são, fundamentalmente, normas-objetivo, isto é, normas que definem fins a alcançar. É o seguinte [...] o significado da cláusula final no art. 174 da Constituição de 1988: a realização dos objetivos visado pelos planos nacionais e regionais de desenvolvimento é determinante para o setor público, porém meramente indicativa para o setor privado.

0 planejamento é também uma atividade direcionada ao futuro. 0 Estado projeta comportamentos dos agentes com o objetivo de ordenar o ambiente econômico, direcionando e induzindo as atividades nele ocorridas para alcançar metas, como por exemplo, maior produção, menor consumo, etc.

Interessante a posição de Eros Grau quanto à não inclusão do planejamento no rol das modalidades de intervenção. Para ele "o planejamento apenas qualifica a intervenção do Estado sobre e no domínio econômico, na medida em que esta, quando conseqüente ao prévio exercício dele, resulta mais racional" (GRAU, 2006, p. 151). A intervenção, nesse sentido, seria justificada e pautada pelas linhas estabelecidas no planejamento estatal. Concatenadas e dirigidas a partir de um projeto organizado para a economia, as atividades de intervenção, por exemplo, a normativa, se fariam mais racionais e seguindo um mesmo propósito estabelecido no plano. É por isso que o referido autor diz que o planejamento não se trata de modelo de intervenção, mas apenas "um método a qualificá-la, por torná-la sistematizadamente racional".

Washington Peluso Albino de Souza (2003, p. 369), que classifica o Planejamento como "uma 'técnica' de intervenção do Estado no domínio econômico", aduz a diferença entre Planejamento e Plano. Para o jurista, planejamento liga-se "à idéia de racionalizar 0 emprego de meios disponíveis para deles retirar os efeitos mais favoráveis" (SOUZA, 2003, p. 370); seria o agir estatal determinado à aplicação da "planificação". 0 plano, por sua vez, é 0 documento que contém os dados do contexto econômico que se analisa e os meios pelos quais se quer atingir os objetivos pretendidos. 0 plano é, portanto, uma peça técnica.

Para que o plano produza, legitimamente, seus efeitos na realidade econômica, é preciso inseri-lo no ordenamento jurídico do Estado, por meio de sua conversão em lei, atendendo aos seus requisitos e processos democráticos. A partir daí, a peça técnica (Plano) transforma-se na "Lei do Plano" (SOUZA, 2003, p. 371). Por isso, para a elaboração desse planejamento, o ente estatal deve se orientar segundo dimensões de ordem técnica e política, além da jurídica, como observa Scott (2000, p. 132). Dimensão de ordem técnica 
porque um planejamento econômico, sobretudo na complexidade dos mercados atuais, não pode ocorrer sem que dele participem especialistas técnico-científicos capazes de articular as necessidades, objetivos e consequêencias que advirão do plano. Já a dimensão política ligase ao fato de que a escolha das opções mais convenientes passa por um processo de discussão e deliberação política.

Souza (2003, p. 384-387) apresenta vários exemplos de dispositivos constitucionais que fazem referência ao planejamento, dos quais se destacam a atribuição do Congresso Nacional de dispor sobre o plano plurianual (Art. 48, II CF); a atribuição da União de executar "planos nacionais e regionais de ordenação do território e de desenvolvimento econômico e social" (Art. 21, IX CF); o controle do cumprimento das metas contidas no plano plurianual (Art. 74, I CF); a atribuição do Município de promover o adequado ordenamento territorial, mediante planejamento do solo urbano (Art. 30, VII) e de elaborar o Plano Diretor, destinado a cidades com mais de 20.000 (vinte mil) habitantes, etc.

A Lei do Plano, posto que dotada de roupagem jurídica, vai orientar, no prazo de sua vigência, toda a política econômica do país. Na lição de Souza (2003, p. 387):

Para a execução dessa política econômica, utiliza-se todo o instrumental legal infraconstitucional referente à vida econômica, em geral, e à estrutura administrativa do País, de modo direto e indireto. Os diplomas legais nele baseados são da mais diversa natureza, podendo constar de leis que modificam ou alteram leis anteriores e, por isso, continuam tendo eficácia mesmo depois de terminada a vigência da lei do Plano, o mesmo podendo acontecer com os Conselhos, Comissões e demais órgãos por ele criados.

Diante destas breves considerações, pode-se dizer que o planejamento é um importante meio de efetivação da intervenção estatal sobre a ordem econômica, pois, a partir da elaboração do documento técnico que traça as linhas do planejamento, e sua posterior obtenção do status de Lei, vai determinar toda a política econômica do Estado, balizando as demais modalidades de intervenção (fiscalização e incentivo) e orientando a atuação da iniciativa privada (se convencê-la, racionalmente), sempre com o propósito de atingir os fins constitucionais do Estado e de sua Ordem Econômica, constantes no Art. 170. 


\section{Conclusão}

Os diferentes modelos de Estado que se sucederam a partir do surgimento do Estado Moderno, a começar pelo formato Absolutista, passando pelos Estados Liberal, Social e Neoliberal, servem de referenciais, principalmente quanto aos seus fundamentos políticos e filosóficos, acerca das possibilidades de atribuição de funções interventoras ao Estado brasileiro sobre o domínio econômico nacional.

A Constituição Federal do Brasil, no título que trata da Ordem Econômica, estabelece os seus fundamentos, princípios e fins, no Artigo 170. Nota-se, neste dispositivo constitucional, a coexistência de princípios advindos da doutrina liberal, como a liberdade de iniciativa, o direito à propriedade privada, a livre concorrência, etc., com princípios que emergiram com os ideais de justiça social, subjacentes ao Estado de Bem-Estar, por exemplo, a atribuição de função social à propriedade, a valorização do trabalho humano, 0 direito à existência digna a todos os indivíduos, etc.

A opção do legislador constituinte, quanto ao sistema econômico a ser instituído no Brasil, foi pelo modelo capitalista de produção, pois se estabeleceu a livre iniciativa como fundamento da Ordem Econômica. No entanto, é nítido o interesse constitucional na redução dos problemas sociais que, na prática do liberalismo estatal puro, restaram demonstrados. Portanto, a economia de mercado, inaugurada em 1988, convive com ditames de justiça social, de modo a valorizar o trabalho humano.

Dessa forma, a intervenção estatal sobre o domínio econômico torna-se necessária e, constitucionalmente, legítima para ser exercida não contra o mercado, mas a seu favor, corrigindo distorções e evitando os abusos.

O Art. 174 da Constituição Federal de 1988 autoriza a intervenção do Estado desde que se busquem os fins da Ordem econômica, com ações pautadas nos princípios estabelecidos no Art. 170 da Lei M aior. Atribui-se ao Estado o papel de normatizar e regular a atividade econômica, por meio da fiscalização, do incentivo e do planejamento para que se concretizem os valores essenciais à ordem econômica do Brasil.

A interpretação do Art. 219 do Diploma Constitucional também fortalece o entendimento no sentido de legitimar a intervenção estatal sobre o domínio econômico para efetivar o desenvolvimento sócio-econômico e o bem-estar da população, posto que 0 mercado é um patrimônio nacional e não um fim em si mesmo. 


\section{Referências}

ANDERSON, Perry. Balanço do neoliberalismo. In: SADER, Emir; GENTILI, Pablo (Org.). Pósneoliberalismo: as políticas Sociais e o Estado Democrático. Rio de Janeiro: Paz e Terra, 1995.

BARROSO, Luís Roberto. A Ordem Constitucional e os Limites à Atuação Estatal no Controle de Preços. In: BARROSSO, Luís Roberto. Temas de Direito Constitucional (tomo II). Rio de Janeiro: Renovar, 2003.

BASTOS, Celso Ribeiro; M ARTINS, Ives Gandra. Comentários à Constituição do Brasil. São Paulo: Saraiva, 1988. v. 7.

BITTAR, Eduardo C. B. Curso de Filosofia Política. 3. ed. São Paulo: Atlas, 2007.

BONAVIDES, Paulo. Teoria do Estado. 6.ed. rev. ampl. São Paulo: M alheiros Editores, 2007.

DALLARI, Dalmo de Abreu. Elementos de Teoria Geral do Estado. 24. ed. São Paulo: Saraiva, 2003.

GRAU, Eros Roberto. A Ordem Econômica na Constituição de 1988. 11. ed., rev. atual. São Paulo: Malheiros Editores, 2006.

HOBBES, Thomas. Leviatã ou Matéria, Forma e Poder de um Estado Eclesiástico e Civil. Trad. João Paulo Monteiro e M aria Beatriz Nizza da Silva. 2. ed. São Paulo: Abril Cultural, 1979. (Os Pensadores)

LOCKE, John. Segundo Tratado sobre o Governo Civil e outros escritos. 3. ed. Petrópolis: Vozes, 2001.

M OREIRA, Egon Bockmann. Os Princípios Constitucionais da Atividade Econômica. Revista da Faculdade de Direito da Universidade Federal do Paraná, Curitiba, n. 45, p. 103-112, 2006.

PIM ENTA, Paulo Roberto Lyrio. Contribuições de Intervenção no Domínio Econômico. São Paulo: Dialética, 2002.

SCOTT, Paulo Henrique Rocha. Direito Constitucional Econômico: Estado e Normalização da Economia. Porto Alegre: Sérgio Antônio Fabris Editor, 2000.

SOUZA, Washington Peluso Albino de. Primeiras Linhas de Direito Econômico. 5. ed. São Paulo: LTr, 2003.

STRECK, Lênio Luiz; M ORAIS, José Luis Bolzan. Ciência Política e Teoria Geral do Estado. 3. ed. Porto Alegre: Livraria do Advogado, 2003.

VILANOVA, Lourival. Escritos Jurídicos e Filosóficos. São Paulo: Axis M vndi: IBET, 2003. v. 1. 